\title{
TINJAUAN KINETIKA KIMIA DAYA HAMBAT MINYAK DAUN CENGKEH (Syzygium aromaticum) DAN HASIL MIKROENKAPSULASINYA TERHADAP Eschericia coli
}

\section{Chemical Kinetics Inhibition Clove Leaves Oil (Syzygium aromaticum) and It's Microencapsulat Against Escherichia Coli}

\author{
Laily Nurliana $^{1 *}$, Desi Kurniawati ${ }^{1}$, Rustam Musta ${ }^{2}$, Laode Abdul Kadir ${ }^{1}$, \\ Siti Nurjana ${ }^{2}$, Fitria Dewi ${ }^{1}$ \\ ${ }^{1}$ Chemistry Department, Mathematic and Nature Science Faculty, Halu Oleo University, Kendari \\ ${ }^{2}$ Chemistry Department, Teacher Training dan Education Faculty, Halu Oleo University, Kendari \\ *Corresponding author, e-mail: laylinurliana@gmail.com
}

Received: Sep. 2019 Published: Jan. 2020

\begin{abstract}
The secondary metabolite compounds contained in clove leaves oil have the potential to be antibacterial Escherichia coli. The kinetic analysis is based on the inhibition zone formed as a result of the inhibition of clove leaves oil and the results of microencapsulation on E. coli bacteria. The determination of the inhibition zone uses the disk diffusion method by using amoxicillin as a positive control and tween oil as a negative control. The kinetic review is intended to find out the antibacterial inhibitory reaction process by determining the reaction order (n), rate constant $(\mathrm{k})$ as well as the $\mathrm{A}_{\mathrm{t}}-\mathrm{A}_{\mathrm{o}}-\mathrm{t}$ relationship of clove leaves oil and the results of its microencapsulation. Based on the research results obtained by the reaction order (n) of clove oil as an antibacterial $E$. coli is $\mathrm{n}=0.1913$; with the rate constant $\mathrm{k}=5.7679$. The reaction order (n) results of microencapsulation as antibacterial E. coli are 0.5039; with the rate constant $\mathrm{k}=4.7323$. The relationship of $\mathrm{A}_{\mathrm{t}}-\mathrm{A}_{\mathrm{o}}-\mathrm{t}$ for the reaction of clove leaves oil as antibacterial $E$. coli is $A_{t}=\left(A_{0}^{0,8}-5 t\right)^{1,25}$. The relationship of $A_{t}-A_{0}-t$ for the reaction of clove leaves oil as a result of microencapsulation as antibacterial $E$. coli is $\left(\frac{1}{A_{t}{ }^{0,5}}-\frac{1}{{A_{o}}^{0,5}}\right)=2,35 t$. The minimum effective consentration equal to the positive control inhibition will be obtained if $8.57 \%$ for clove oil or a coating of 1: 3481 for microencapsulated clove oil is used.
\end{abstract}

Keywords: Kinetics, clove leaves oil, microencapsulation, E. coli.

\section{PENDAHULUAN}

Cengkeh (Syzygium aromaticum) merupakan tumbuhan yang menghasilkan minyak atsiri dengan banyak potensi dan telah banyak diteliti misalnya potensi antibakteri (Hosaain. Dkk., 2014), efek antioksidan Gulcin (2012) dan antifungi (Eman-Abdeen and El-Diasty, 2015). Minyak daun cengkeh dapat diperoleh dengan metode destilasi uap, mempunyai komponen utama eugenol dengan kadarnya sekitar 74,24\% dan $\beta$-kariofilen 12,79\% (Amelia, dkk., 2017). Kandungan eugenol yang merupakan metabolit sekunder golongan fenilpropanoid tersebut yang berpotensi sebagai antibakteri yang dapat menghambat pertumbuhan bakteri yaitu bekerja dengan meracuni sitoplasma, merusak dan menembus dinding serta mengendapkan protein sel bakteri (Devi, dkk., 2010)
Minyak atsiri mempunyai kelemahan antara lain mudah teroksidasi dan mudah menguap (volatil). Hal tersebut dapat diatasi dengan menggunakan metode mikroenkapsulasi (Nurliana, dkk., 2016; Risnawati, dkk., 2017). Mikroenkapsulasi adalah metode yang umumnya digunakan untuk menangani minyak dalam bentuk cairan, sehingga perubahan bentuk cairan minyak menjadi serbuk akan lebih mudah ditangani alam penanganannya (Soliman, dkk., 2013).

Penelitian tentang aktifitas antibakteri minyak atsiri juga telah banyak dilakukan $d$ iantaranya dilaporkan oleh Li, dkk. (2014) meninjau aktivitas antibakteri minyak Litsea cubeba pada Escherichia coli dengan teknik Toxic Food dan melaporkan bahwa MIC dan MBC sebesar $0,125 \%$ dan melaporkan pula bahwa 
dengan pendekatan kinetic diperoleh bahwa konsentrasi $0,0625 \%$ sudah dapat memberikan efek yang sama walaupun dengan proses yang lebih lama. Cortes-Rojas (2014) melaporkan bahwa minyak cengkeh sudah menunjukkan daya hambat yang baik pada konsentrasi $1 \%$ untuk bakteri-bakteri E. coli, Staphylococcus aureus dan Bacilus cereus dan akan patogen pada konsentrasi $3 \%$.

Hasil penelitian tersebut menunjukkan hubungan antibakteri dengan aktivitasnya. Namun demikian belum dilaporkan tinjauan kinetikanya, guna melihat proses kerja reaksi penghambatan oleh antibakteri dari sudut pandang tahapan kinetika kimia. Pengetahuan akan orde reaksi (n) tetapan laju (k) serta hubungan $\mathrm{A}_{\mathrm{t}}-\mathrm{A}_{\mathrm{o}}-\mathrm{t}$ sangat baik digunakan untuk memahami mekanisme kerja suatu antibakteri. Hal ini penting melengkapi pengetahuan tentang aktivitas antibakteri secara keseluruhan termasuk menentukan konsentrasi minimum yang dianjurkan untuk digunakan sebagai antibakteri dengan menggunakan metode kinetika kimia.

Penelitian sebelumnya tentang kinetika telah dilakukan penentuan konsentrasi minimum efektif minyak daun cengkeh pada penghambatan jamur Candida albicans yaitu sebesar 17,6\% (Musta dan Nurliana, 2019). Berdasarkan latar belakang tersebut maka dalam penelitian ini ditinjau metode kinetika kimia untuk penentuan konsentrasi minimum minyak daun cengkeh yang efektif untuk antibakteri $E$. coli yang dilengkapi dengan penentuan orde reaksi (n) tetapan laju (k) serta hubungan $\mathrm{A}_{\mathrm{t}}-\mathrm{A}_{\mathrm{o}}-\mathrm{t}$ pada tahap-tahap mekanisme kerja antibakteri tersebut.

\section{METODOLOGI}

Alat

Alat yang digunakan dalam penelitian ini adalah inkubator, neraca analitik (Acis), autoklaf (Wisecclave), waterbath (HWS24), lemari pendingin (SHARP), pipet mikro (DRAGON ONEMED), laminar air flow cabinet, shaker incubator (Ratex), lampu UV, hot plate, mistar, spidol, tabung eppendorf, kawat ose, cawan petri (Pyrex), gelas ukur (Pyrex), gelas kimia (Pyrex), erlenmeyer (Pyrex), corong (Pyrex), corong pisa (Pyrex), spatula, vortex, pipet ukur, oven, pipet tetes, botol vial, kertas label dan kapas steril.

\section{Bahan}

Bahan yang digunakan dalam penelitian ini adalah minyak daun cengkeh dan hasil mikroenkapsulasi minyak daun cengkeh dari penelitian sebelumnya (Nurliana, dkk., 2019), Escherichia coli ATCC 35219, amoxicillin, pepton $2 \%$, agar $4 \%$, NaCI $1 \%$, minyak tween, dan akuades.

\section{Prosedur Kerja \\ Sterilisasi alat dan bahan}

Seluruh alat dicuci bersih dan dikeringkan. Botol vial, tabung reaksi, Erlenmeyer, cawan petri dibungkus dengan kertas. Kemudian semuanya disterilkan dengan autoklaf pada suhu $121^{\circ} \mathrm{C}$ selama 15 menit. Pengerjaan aseptis dilakukan di dalam laminar air flow yang sebelumnya telah dibersihkan dengan larutan alkohol 70\% lalu disterilkan dengan lampu UV yang dinyalakan selama kurang lebih 1 jam sebelum digunakan dalam proses antibakteri (Nurliana, 2016).

\section{Peremajaan Mikroorganisme}

Bakteri E. coli diremajakan dengan mentransfer 1 atau 2 ose dari bakteri, kemudian dimasukkan ke dalam tabung reaksi yang berisi $10 \mathrm{~mL}$ media cair steril ( $2 \%$ pepton, $1,5 \%$ yet ekstrak dan $4 \% \mathrm{NaCl}$ ) dan diinkubasi selama 24 jam (Sultana, 2015).

\section{Uji Aktivitas}

Media NA sebanyak $20 \mathrm{~mL}$, kemudian dimasukkan dalam efendorf $50 \mathrm{~mL}$ dan ditambahkan $10 \mu \mathrm{L}$ inokulum bakteri E. coli dan dihomogenkan. Setelah homogen dituang dalam cawan petri dengan gerakan melingkar sampai media merapat pada permukaan cawan petri, kemudian didiamkan beberapa menit sampai padat. Kemudian ditempatkan kertas cakram (berdiameter $0,5 \mathrm{~cm}$ ) yang telah direndam dalam larutan uji minyak daun cengkeh $(100 \%, 75 \%$, $50 \%, 25 \%$ dan larutan standar) pada permukaan media padat. Setelah itu cawan petri ditutup rapat dan dibungkus dengan plastik wrap. Kemudian diinkubasi selama 1 x 24 jam di suhu ruang dan diukur zona hambat yang terbentuk (Kumar, dkk., 2014). Perlakuan yang sama untuk uji aktivitas pada sampel mikrokapsul minyak daun cengkeh (Nurliana, dkk., 2019).

\section{Kinetika Penentuan Konsentrasi Minyak Atsiri Cengkeh yang Efektif untuk Antibakteri E. coli}

Dybkov (2013) menyatakan bahwa persamaan laju dapat dinyatakan: 


$$
\mathrm{r}=\mathrm{k}[\mathrm{A}]^{\mathrm{n}}
$$

Dengan : $\mathrm{r}=$ Laju reaksi, $\mathrm{k}=$ Konstanta laju reaksi, $[\mathrm{A}]=$ Konsentrasi zat, $\mathrm{n}=$ Orde reaksi. Laju reaksi (r) dapat dipandang sebagai bertambahnya hasil reaksi atau berkurangnya reaktan setiap satuan waktu (Petrucci 1992). Disisi lain, reaksi suatu antibakteri terhadap bakteri uji tertentu dapat lihat dari zona hambatnya. Mawan dkk. (2018) menyatakan bahwa semakin tinggi konsentrasi maka semakin luas zona hambat yang terbentuk. Senada dengan itu, Uddhav and Sivagurunathan (2016) menyatakan bahwa diameter zona hambat berbanding langsung dengan kepekatan isolat. (Saeed, dkk., 2013) melaporkan bahwa dapat dibuktikan diameter zona bening meningkat secara signifikan sebagai akibat peningkatan konsentrasi ekstrak. Hal ini mengindikasikan bahwa zona bening yang terbentuk merupakan fungsi konsentrasi. Oleh karena itu, laju laju reaksi dapat dipelajari dari laju pembentukan zona beningnya. Besarnya laju pembentukan zona bening secara rata-rata dapat ditentukan dengan:

$$
\mathrm{r}_{\mathrm{zb}}=\frac{\mathrm{D}_{\mathrm{zb}}}{\mathrm{t}}=\mathrm{k}[\mathrm{A}]^{\mathrm{n}}
$$

Dengan : $r_{\mathrm{zb}}=$ laju pembentukan zona bening, $\mathrm{D}_{\mathrm{zb}}$ = diameter zona bening, $\mathrm{t}=$ masa inkubasi. Waktu (t) dalam penelitian ini sama untuk setiap variasi konsentrasi uji karena merupakan masa inkubasi maka laju pembentuan zona bening sebenarnya hanya semata-mata ditentukan oleh variasi konsentrasi dan untuk keperluan analisis penentuan orde dan konstanta laju menggunakan metode ini, variable waktu merupakan variabel konstan, sehingga:

$$
\mathrm{r}_{\mathrm{zb}} \approx \mathrm{D}_{\mathrm{zb}}=\mathrm{k}[\mathrm{A}]^{\mathrm{n}}
$$

Dengan demikian akan berlaku:

$$
\mathrm{D}_{\mathrm{zb}}=\mathrm{k}[\mathrm{A}]^{\mathrm{n}} \text {. }
$$

\section{Keterangan :}

$\mathrm{D}_{\mathrm{zb}}=$ Diameter zona bening

$\mathrm{k}=$ Konstanta laju

$[\mathrm{A}]=$ Kosentrasi

$\mathrm{n}=$ Orde reaksi.

Dengan menghitung nilai ln-nya maka akan diperoleh bentuk persamaan: $\ln \mathrm{D}_{\mathrm{zb}}=\ln \mathrm{k}+\mathrm{n} \ln$ [A] suatu bentuk persamaan regresi linear yang bentuk umumnya: $y=a+b x$ hal ini berarti bahwa jika dibuat plot hubungan $\ln [\mathrm{A}]$ terhadap $\ln \mathrm{D}_{\mathrm{zb}}$ maka akan diperoleh:

a (intersep) $=\ln \mathrm{k}$, yang berarti bahwa $\mathrm{k}=\mathrm{e}^{\mathrm{a}}$ dimana $\mathrm{b}($ slope $)=\mathrm{n}=$ orde. Berdasarkan orde reaksi (n) dan tetapan laju (k) yang telah diketahui akan ditentukan hubungan $\mathrm{A}_{\mathrm{t}}-\mathrm{A}_{\mathrm{o}} \mathrm{t}$ setelah menyelesaikan persamaan dengan bentuk umum:

$$
-\frac{\partial \mathrm{A}}{\partial \mathrm{t}}=\mathrm{kA}^{\mathrm{n}}
$$

\section{HASIL DAN PEMBAHASAN}

\section{Hasil Uji Aktifitas Antibakteri}

Aktivitas antibakteri minyak daun cengkeh menggunakan metode difusi cakram steril. Pengujian menggunakan amoxilin sebagai kontrol positif dan minyak tween sebagai kontrol negatif. Penggunaan amoxilin sebagai kontrol positif dikarenakan amoxilin adalah antibakteri yang sangat baik digunakan untuk mengobati berbagai macam infeksi bakteri (Kaur, dkk., 2011). Minyak tween sebagai kontrol negatif berperan sebagai emulgator antara minyak daun cengkeh dan media Nutrien Agar (NA). Minyak Tween adalah suatu pengemulsi agar air dan minyak menjadi homogen. Tween 80 merupakan ester asam lemak polioksietilen sorbitan, dengan nama kimia polioksietilen 80 sorbitan monooleat $\left(\mathrm{C}_{64} \mathrm{H}_{124} \mathrm{O}_{26}\right)$ (Prijatmoko, dkk., 2018).

Hasil analisis uji aktivitas antibakteri minyak daun cengkeh dalam menghambat pertumbuhan bakteri E. coli dilihat pada Tabel 1. Tabel 1 menunjukkan bahwa tiap variasi konsentrasi minyak daun cengkeh berbeda-beda nilai zona bening yang diperoleh tergantung pada konsentrasi masing-masing. Data tersebut menunjukkan bahwa diameter ditiap-tiap konsentrasi $25 \%, 50 \%$, 75\% dan $100 \%$ yaitu secara berturut-turut 11,$2 ; 11,4 ; 12,3$ dan 15,2 $\mathrm{mm}$. Berdasarkan hasil tersebut menunjukkan bahwa semakin besar konsentrasi minyak daun cengkeh maka makin besar pula nilai zona bening yang diperoleh. Kumar (2014) menjelaskan bahwa kriteria kekuatan daya hambat antibakteri dapat dibedakan berdasarkan parameter sebagai berikut: diameter zona hambat $<7 \mathrm{~mm}$ dikategorikan tidak ada aktivitas antibakteri, zona hambat 7-12 mm dikategorikan sedang, dan zona hambat $>12 \mathrm{~mm}$ dikategorikan kuat. Berdasarkan hasil penelitian konsentrasi minyak daun cengkeh tergolong ke dalam zona hambat sedang pada konsentrasi $25 \%$ dan $50 \%$ dan pada konsentrasi $75 \%$, dan $100 \%$ tergolong kategori kuat. 
Laily Nurliana dkk. / Indo. J. Chem. Res., 2020, 7(2), 151-158

Tabel 1. Hasil uji aktivitas antibakteri minyak daun cengkeh

\begin{tabular}{cc}
\hline Sampel & $\begin{array}{c}\text { Zone bening } \\
(\mathrm{mm})\end{array}$ \\
\hline $100 \%$ & $15,2 \pm 0,7$ \\
$75 \%$ & $12,3 \pm 0,3$ \\
$50 \%$ & $11,4 \pm 0,2$ \\
$25 \%$ & $11,2 \pm 0,2$ \\
$(-)$ control & $0,0 \pm 0,0$ \\
(+) control & $8,7 \pm 0,6$ \\
\hline
\end{tabular}

Tabel 2. Hasil uji aktivitas antibakteri mikrokapsul minyak daun cengkeh (Nurliana,

\begin{tabular}{lc}
\multicolumn{1}{c}{ dkk., 2019) } \\
\hline \multicolumn{1}{c}{ Sampel } & $\begin{array}{c}\text { Zona bening } \\
(\mathrm{mm})\end{array}$ \\
\hline $\begin{array}{l}\text { minyak : maltodekstrin : } \\
\text { minyak: maltodekstrin : }\end{array}$ & 9.9 \\
$\begin{array}{l}\text { 1:6 } \\
\text { minyak : maltodekstrin }\end{array}$ & 11.3 \\
$: 1: 8$ \\
$\begin{array}{l}\text { minyak: maltodekstrin } \\
: 1: 10\end{array}$ \\
$\begin{array}{l}\text { minyak : maltodekstrin } \\
: 1: 12\end{array}$ \\
$\begin{array}{l}-) \text { control } \\
(+) \text { control }\end{array}$ \\
\hline
\end{tabular}

Adapun hasil uji aktivitas antibakteri pada mikrokapsul minyak daun cengkeh (Tabel 2.) merujuk pada Nurliana (2019). Terlihat bahwa pada perbandingan minyak : maltodektrin 1:4 dan 1:6 diperoleh daya hambat dengan aktifitas sedang. Sementara itu, untuk perbanding 1:8; 1:10 dan 1: 12 termasuk dalam kategori kuat (Nurliana, 2019). Bahan yang dimikrokapsul merupakan minyak murni atau $100 \%$.

Kandungan senyawa metabolit sekunder pada minyak daun cengkeh seperti eugenol yang termasuk golongan fenilpropanoid dan $\beta$ karyofilen yang termasuk golongan seskuiterpen, diduga mempunyai potensi untuk memberikan efek toksik pada sel bakteri. Sifat hidrofobik senyawa eugenol membuatnya lebih mudah untuk memasuki bagian lipopolisakarida dari membran sel bakteri, terutama bakteri gram negatif dan mengubah struktur dinding sel, menyebabkan kebocoran pada bagian intraseluler sel bakteri dan menyebabkan kematian (Devi, dkk., 2010 and Xu, dkk., 2016).
Kinetika Minyak daun cengkeh (Syzigium Aromaticum) dan Hasil Mikroenkapsulasinya sebagai Antibakteri E. coli

Analisis kinetika kimia minyak daun cengkeh sebagai antibakteri E. coli ditentukan dengan menggunakan persaamaan regresi linear yang diturunkan dari persamaan kinetika kimia. Analisis mengunakan regresi linear tersebut menghasilkan grafik sebagai mana ditunjukkan pada Gambar 1. Gambar 1. memperlihatkan persamaan regresi dengan bentuk $y=$ $0,1913 x+1,7523$. Persamaan regresi ini memperlihatkan bahwa orde reaksi (n) minyak minyak daun cengkeh terhadap bakteri $E$. coli adalah 0,1913 dengan tetapan laju $\mathrm{e}^{1,7523}=5,7679$, yang juga berlaku untuk masa inkubasi pengukuran zona bening dalam penelitian ini yakni 24 jam. Orde reaksi sebesar 0,1913 memperlihatkan nilai orde yang berada diantara nilai 0 dan 1 . Triyono, dkk. (1998) menyatakan bahwa jika reaksi berorde nol maka laju tidak ditentukan oleh reaktannya, sementara itu Dogra (1990) menyatakan bahwa bila reaksi berorde satu maka laju reaksi berbanding lurus dengan konsentrasinya.

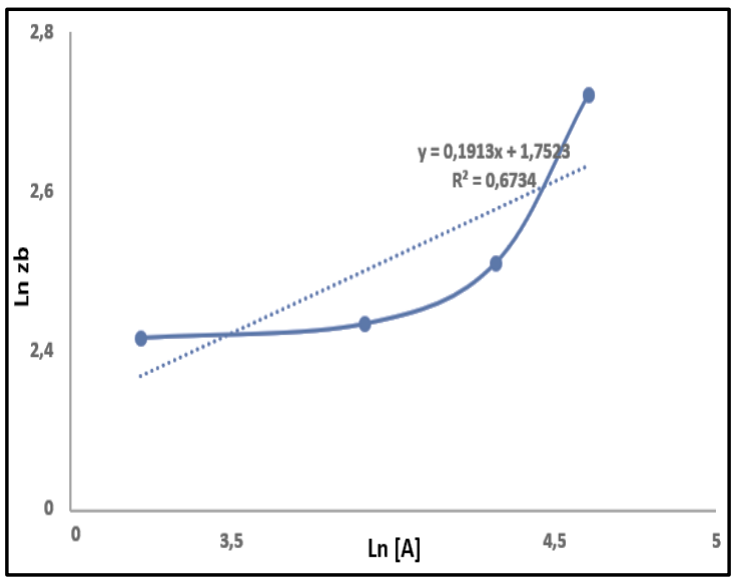

Gambar 1. Plot ln $[\mathrm{A}]$ vs $\ln$ zona bening

Hal ini berarti bahwa ada pengaruh konsentrasi minyak minyak daun cengkeh terhadap zona bening yang terbentuk namun tidak terlalu besar. Nilai $\mathrm{k}=5,7679$ menunjukkan pengaruh tetapan laju yang besar terhadap zona bening yang terbentuk. Dogra and Dogra (1990) menyatakan bahwa tetapan laju merupakan laju reaksi bila konsentrasi adalah 1 . Hal ini dapat diartikan $5.7679 \mathrm{~mm}$ merupakan zona bening yang akan terbentuk bila konsentrasi minyak daun cengkeh adalah $1 \%$. 
Persamaan regresi yang diperoleh memperlihatkan nilai $\mathrm{r}^{2}=0,6734$ yang berarti bahwa korelasi dua variable yang tentukan memiliki hubungan dalam kategori kuat (Sudijono., 2015).

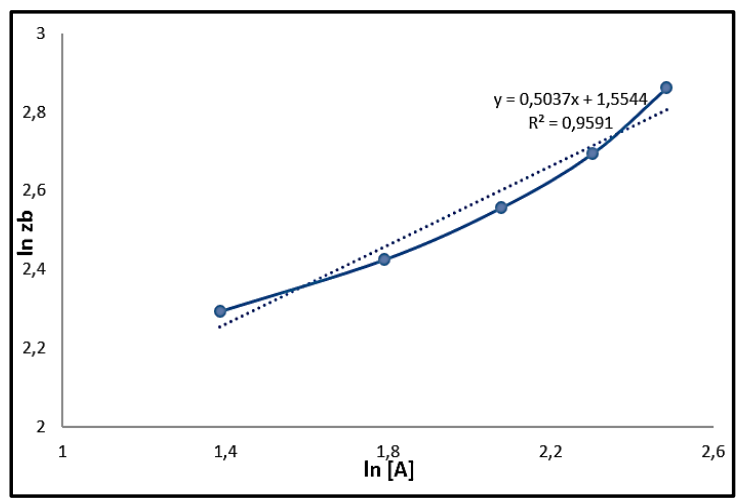

Gambar 2. Plot ln [A] vs ln zona bening

Hasil perhitungan yang diperoleh dari persamaan regresi kemudian dapat dituliskan dalam bentuk persamaan:

$$
\mathrm{Zb}=5,7679[\mathrm{C}]^{0.1913}
$$

Hubungan $\mathrm{A}_{\mathrm{t}}-\mathrm{A}_{\mathrm{o}}-\mathrm{t}$ dapat ditentukan setelah $\mathrm{k}$ dan n diketahui sebagai berikut:

$$
\begin{aligned}
& -\frac{\partial \mathrm{A}}{\partial \mathrm{t}}=\mathrm{k} \mathrm{A}^{\mathrm{n}} \\
& -\frac{\partial \mathrm{A}}{\mathrm{A}^{\mathrm{n}}}=\mathrm{k} \cdot \partial \mathrm{t} \\
& -\int \frac{\partial \mathrm{A}}{\mathrm{A}^{0,1913}}=\int \mathrm{k} \cdot \partial \mathrm{t} \\
& -\int \frac{1}{\mathrm{~A}^{0,1913}} \partial \mathrm{A}=\int \mathrm{k} \cdot \partial \mathrm{t} \\
& -\int \mathrm{A}^{-0,1913} \partial \mathrm{A}=\mathrm{k} \cdot \mathrm{t} \\
& -\left(\frac{1}{-0,1913+1} \mathrm{~A}^{-0,1913+1} \int_{\mathrm{A}_{0}}^{\mathrm{A}_{\mathrm{t}}}\right)=\mathrm{kt} \\
& -\left(\frac{1}{0,8087} \mathrm{~A}^{0,8087} \int_{\mathrm{A}_{0}}^{\mathrm{A}_{\mathrm{t}}}\right)=\mathrm{kt} \\
& -\left(\frac{1}{0,8087} \mathrm{~A}_{\mathrm{t}}^{0,8087}-\frac{1}{0,8087} \mathrm{~A}_{0}^{0,8087}\right)=\mathrm{kt} \\
& \frac{1}{0,8087} \mathrm{~A}_{0}^{0,8087}-\frac{1}{0,8087} \mathrm{~A}_{\mathrm{t}}{ }^{0,8087}=\mathrm{kt} \\
& \frac{1}{0,8087}\left(\mathrm{~A}_{0}{ }^{0,8087}-\mathrm{A}_{\mathrm{t}}^{0,8087}\right)=\mathrm{kt} \\
& \mathrm{A}_{0}^{0,8087}-\mathrm{A}_{\mathrm{t}}^{0,8087}=0,8087 \mathrm{kt} \\
& \mathrm{A}_{0}^{0,8087}-\mathrm{A}_{\mathrm{t}}^{0,8087}=0,8087 \times 5,7679 \mathrm{t} . \\
& \mathrm{A}_{0}^{0,8087}-\mathrm{A}_{\mathrm{t}}^{0,8087}=4,6644 \mathrm{t} \\
& \mathrm{A}_{\mathrm{t}}^{0,8087}=\mathrm{A}_{0}^{0,8087}-4,6644 \mathrm{t}
\end{aligned}
$$

Jika $0,8087 \approx 0,8$ dan $4,6644 \approx 5$ maka dapat diperoleh hubungan yang lebih sederhana:

$$
\mathrm{A}_{\mathrm{t}}{ }^{0,8}=\mathrm{A}_{0}^{0,8}-5 \mathrm{t}
$$

$A_{t}=\left(A_{0}^{0,8}-5 t\right)^{1,25}$

Adapun analisis kinetika kimia minyak daun cengkeh hasil mikroenkapsulasi sebagai antibakteri $E$. coli juga ditentukan dengan menggunakan persamaan regresi linear yang sama dengan menganggap [A] adalah perbandingan penyalut yang digunakan dan hasilnya ditunjukkan pada Gambar 2. Gambar 2. memperlihatkan persamaan regresi dengan bentuk $\mathrm{y}=0,5037 \mathrm{x}+1,5544$ dengan $\mathrm{r}^{2}=0,9591$. Persamaan regresi ini memperlihatkan bahwa orde reaksi (n) minyak minyak daun cengkeh terhadap bakteri E. coli adalah 0,5037 dengan tetapan laju $\mathrm{e}^{1,5544}=4,7323$ yang juga berlaku untuk masa inkubasi pengukuran zona bening dalam penelitian ini yakni 24 jam.

Orde reaksi sebesar 0,5037 memperlihatkan besarnya pengaruh konsentrasi terhadap zona bening yang terbentuk, yang dapat diartikan bahwa setiap peningkatan bahan penyalut 1 satuan akan meningkatkan zona bening sebesar bilangan pangkat 0,5037. Triyono, dkk. (1998) menyatakan bahwa orde reaksi dapat dipandang sebagai komponen aktif secara kinetika yang besarnya dapat berupa bilangan bulangan tetapi dapat pula berupa pecahan bahkan dapat pula bernilai negatif. Adapun nilai $\mathrm{k}=4,7323$ memperlihatkan pengaruh tetapan laju terhadap zona bening yang terbentuk. Dogra and Dogra (1990) menyatakan bahwa tetapan laju merupakan laju reaksi bila konsentrasi adalah 1. Hal ini dapat diartikan bahwa 4,7323 merupakan zona bening yang akan terbentuk bila konsentrasi perbandingan penyalut yang digunakan adalah $1: 1$. Persamaan regresi yang diperoleh memperlihatkan nilai $\mathrm{r}^{2}=0,9591$ yang berarti bahwa korelasi dua variable yang tentukan memiliki hubungan dalam kategori sangat kuat (Sudijono, 2015).

Hasil perhitungan yang diperoleh dari persamaan regresi kemudian dapat dituliskan dalam bentuk persamaan:

$\mathrm{Zb}=4,7323[\mathrm{C}]^{0,5037}$

Hubungan $\mathrm{A}_{\mathrm{t}}-\mathrm{A}_{\mathrm{o}}-\mathrm{t}$ dapat ditentukan setelah $\mathrm{k}$ dan $\mathrm{n}$ diketahui sebagai berikut:

$$
\begin{aligned}
& -\frac{\partial \mathrm{A}}{\partial \mathrm{t}}=\mathrm{k} \mathrm{A}^{\mathrm{n}} \\
& -\frac{\partial \mathrm{A}}{\mathrm{A}^{\mathrm{n}}}=\mathrm{k} \cdot \partial \mathrm{t}
\end{aligned}
$$




$$
\begin{aligned}
& -\int \frac{\partial \mathrm{A}}{\mathrm{A}^{0,5037}}=\int \mathrm{k} \cdot \partial \mathrm{t} \\
& -\int \frac{1}{\mathrm{~A}^{0,5037}} \partial \mathrm{A}=\int \mathrm{k} \cdot \partial \mathrm{t} \\
& -\int \mathrm{A}^{-0,5037} \partial \mathrm{A}=\mathrm{k} \cdot \mathrm{t} \\
& -\left(\frac{1}{-0,5037+1} \mathrm{~A}^{-0,5037+1} \int_{\mathrm{A}_{0}}^{\mathrm{A}_{\mathrm{t}}}\right)=\mathrm{kt} \\
& \left(\frac{1}{0,4963} \mathrm{~A}^{0,4963} \int_{\mathrm{A}_{0}}^{\mathrm{A}_{\mathrm{t}}}\right)=\mathrm{kt} \\
& \left(\frac{1}{0,4963 A_{t}{ }^{0,4963}}-\frac{1}{0,4963 A_{o}{ }^{0,4963}}\right)=\mathrm{kt} \\
& \frac{1}{0,4963}\left(\frac{1}{A_{t}^{0,4963}}-\frac{1}{A_{o}^{0,4963}}\right)=\mathrm{kt} \\
& \left(\frac{1}{A_{t}^{0,0,4963}}-\frac{1}{A_{o}^{0,0,4963}}=0,4963 \mathrm{kt}\right. \\
& \left(\frac{1}{A_{t}^{0,4963}}-\frac{1}{A_{o}^{0,4963}}=0,4963 \times 4,7323 \mathrm{t}\right. \\
& \left(\frac{1}{A_{t}^{0,4963}}-\frac{1}{A_{o}^{0,4963}}\right)=2,3486 \mathrm{t}
\end{aligned}
$$

Jika $0,4963 \approx 0,5$ dan $2,3486 \approx 2,35$ maka dapat diperoleh hubungan yang lebih sederhana:

$\left(\frac{1}{A_{t}{ }^{0,5}}-\frac{1}{A_{o}{ }^{0,5}}\right)=2,35 \mathrm{t}$

Hasil analisis dalam penentuan orde reaksi dan tetapan laju untuk minyak daun cengkeh cair dan hasil mikroenkapsulasinya terhadap zona bening yang terbentuk menunjukkan perbedaan berturut-turut $\mathrm{n}=0,1913 ; \mathrm{k}=5,7679$ dan $\mathrm{n}=$ 0,$5037 ; \mathrm{k}=4,7323$. Hasil ini memperlihatkan nilai yang berbeda dimana pada minyak daun cengkeh hasil mikroenkapsulasi reaksinya berorde $(\mathrm{n})=$ 0,5037 memiliki orde yang lebih besar dibanidngkan dengan minyak daun cengkeh dengan orde reaksi yang hanya sebesar $(\mathrm{n})=$ 0,1913 . Namun demikian untuk minyak cengkeh tetapan laju reaksi $(\mathrm{k})=5,7679$ lebih besar dari minyak daun cengkeh hasil mikroenkapsulasi dengan tetapan lajunya $\mathrm{k}=4,7323$. Perbedaan ini dapat dijelaskan dengan melihat bahwa tetapan laju (k) dipengaruhi oleh temperatur dan energi aktivasi (Triyono, dkk., 1998). Bila dua reaksi dilakukan pada temperatur yang sama maka perbedaan nilai $\mathrm{k}$ ditentukan oleh energi aktivasi. Menurut Sukardjo (2013) agar terjadi reaksi maka molekul-molekul harus saling bertumbukan dan mempunyai tenaga hingga molekul-molekul menjadi aktif. Keenan, dkk. (1996) menyatakan selama reaksi terjadi, molekul-molekul harus bertabrakan. Hal ini dapat menjelaskan perbedaan nilai k pada dua antibakteri yang digunakan yakni minyak daun engkeh dan hasil mikroenkapsulasinya.
Pada minyak daun cengkeh $\mathrm{k}=5,7679$, lebih rendah dibandingkan dengan hasil mikroenkapsulasi yakni $\mathrm{k}=4,7323$; yang menunjukkan bahwa pada minyak daun cengkeh murni dimana hanya terjadi interaksi partikel minyak daun cengkeh dan bakteri $E$. coli terjadi interaksinya lebih lebih cepat, sementara itu pada hasil mikroenkapsulasi terjadi interaksi selain partikel minyak daun cengkeh dengan bakteri $E$. coli juga ada partikel maltodekstrin sebagai penyalut yang juga berinteraksi dengan minyak daun cengkeh maupun bakteri $E$. coli, hal ini menyebabkan interaksi menjadi lebih lambat.

Adapun orde reaksi menunjukkan bahwa untuk antibakteri menggunakan minyak daun cengkeh dengan $(\mathrm{n})=0,1913$ lebih kecil dari pada hasil mikroenkapsulasi dengan $(\mathrm{n})=0,5039$. Keenan, dkk. (1996) menyatakan bahwa orde reaksi adalah harga eksponen reaktan. Dengan demikian kedua nilai orde yang diperoleh tersebut menunjukkan nilai pangkat dari minyak daun cengkeh dan hasil mikroenkapsulasi dalam mempengaruhi zona bening yang terbentuk. Perbedaan orde dapat dijelaskan dengan memperhatikan bahwa minyak daun cengkeh akan langsung berinteraksi dengan bakteri $E$. coli sehingga penambahan minyak tidak akan memberikan efek besar terhadap interaksi yang sudah terjadi untuk pembentukan zona bening.

Sementara itu adanya penyalut pada hasil mikroenkapsulasi, menyebabkan interaksi minyak daun cengkeh terhadap pembentukan zona bening yang sebenarnya dibutuhkan menjadi kecil dan karenanya penambahan sedikit partikel minyak akan sangat mempengaruhi interaksi dengan bakteri E. coli. Namun demikian secara keseluruhan, zona bening yang terbentuk sebagai akibat pengaruh simultan tetapan laju (k) dan konsentrasi [A] kedua perlakuan memberikan zona bening yang diameternya berkisar antara 9$18 \mathrm{~mm}$.

Konsentrasi minimum minyak cengkeh yang efektif sebagai anti bakteri $E$. coli dapat dihitung: $8,7=5,7679[\mathrm{~A}]^{0,1913}$

$$
\begin{aligned}
{[\mathrm{A}]^{0,1913} } & =8,7 / 5,7679 \\
{[\mathrm{~A}] } & =(1,5083)^{(1 / 0,1913)} \\
{[\mathrm{A}]_{\min } } & =8,57
\end{aligned}
$$

Adapun perbandingan penyalut minimum yang efektif sebagai anti bakteri $E$. coli dapat dihitung:

$$
8,7=4,7323[\mathrm{~A}]^{0,5039}
$$


$[\mathrm{A}]^{0,5039}=8,7 / 4,7323$

[A] $=(1,8384)^{(1 / 0,5039)}$

$[\mathrm{A}]_{\min }=3,3481$

Dengan demikian maka dapat diketahui bahwa agar diperoleh daya hambat yang sama dengan kontrol positif maka harus digunakan konsentrasi sebesar 8,57\% untuk minyak cengkeh atau digunakan penyalut dengan komposisi 1:3481 untuk minyak cengkeh yang dimikroenkapsulasi.

\section{KESIMPULAN}

Berdasarkan hasil peneitian dapat disimpulkan bahwa orde reaksi (n) minyak daun cengkeh sebagai antibakteri $E$. coli adalah n $=$ 0,1913 ; dengan tetapan laju $\mathrm{k}=5,7679$. Adapun orde reaksi (n) hasil mikroenkapsulasi sebagai antibakteri $E$. coli adalah 0,5039; dengan tetapan laju $\mathrm{k}=4,7323$. Hubungan $\mathrm{A}_{\mathrm{t}}-\mathrm{A}_{\mathrm{o}}-\mathrm{t}$ untuk reaksi minyak daun cengkeh sebagai antibakteri $E$. coli adalah $A_{t}=\left(A_{0}^{0,8}-5 t\right)^{1,25}$. Adapun untuk reaksi minyak daun cengkeh hasil mikroenkapsulasi adalah $\left(\frac{1}{A_{t}{ }^{0,5}}-\frac{1}{A_{o}{ }^{0,5}}\right)=2,35 \mathrm{t}$. Konsentrasi minyak cengkeh sebesar $8,57 \%$ dan perbandingan minyak cengkeh terhadap maltodektrin sebesar 1:3481 merupakan konsentrasi minyak cengkeh minimum dan perbandingan penyalut minimum agar diperoleh daya hambat yang sama dengan kontrol positif.

\section{UCAPAN TERIMAKASIH}

Penulis mengucapkan terimakasih kepada pihak LPPM UHO yang telah memberikan bantuan dana pada skim Penelitian Dosen Pemula Internal UHO.

\section{DAFTAR PUSTAKA}

Mawan A. R., Indriwati S.E, Suhadi, 2018, Aktivitas Antibakteri Ekstrak Metanol Buah Syzygium polyanthum terhadap Pertumbuhan Bakteri Escherchia coli, Bioeksperimen, 4(1), 64-68.

Amelia, B., Saepudin, E., Cahyana, A.H., Rahayu, D.U., Sulistyoningrum, A.S., Haib, J., 2017, GC-MS Analysis of Clove (Syzygium aromaticum) Bud Essential Oil from Java and Manado, ISCPMS, 1862, 030082-1-030082-9.

Cortes-Rojas, D.F., Fernandes, C.R. deS., Oliveira, W.P., 2014, Clove (Syzygium aromaticum): A Preciuos Spice, Asian Pac. J. Trop. Biomed, 4(2), 90-96.

Devi, K.P., Nisha, S.A., Sakhtivel, R., Pandian S.K., 2010, Eugenol (An Essential Oil of Clove) Acts as An Antibacterial Agent Against Salmonella Typhi By Distrupting The Cellular Membrane, J. Ethnopharmacol, 130, 107-15.

Dogra, S.K., Dogra, S., 1990, Kimia Fisik dan Soal-soal, UI Press, Jakarta

Dybkov, V.I., 2013, Chemical Kinetics, IPMS Publications, Kyiv, Ukraine

Eman-Abdeen, E., and El-Diasty, E.M., 2015, Antifungal Activity of Clove Oil on Dermatophytes and Other Fungi, Int. J. Adv. Res, 12, 1299-1305.

Gulcin, I., Elmastas, M., Alboun-Enein, H.Y., 2012, Antioxidant Activity of Clove Oil-A Powerful Antioxidant Source, Arabian J. Chemistry, 5, 489-499.

Hossain, M.A., Al-Harbi, S.R., Weli, A.M., AlRiyami, Q., Al-Sabahi, J.N., 2014, Comparison of Chemical Constituents and Antimicrobial Activities of Three Essential Oils from Three Different Brands Clove Samples Collected from Gulf Region, Asian Pac J Trop Dis, 4(4), 262-268.

Kaur, S.P., Rao, R., Nanda, S., 2011, Amoxicillin: A Broad-Spectrum Antibiotic. Int. J. Pharm. Sci., 3(3), 30-37

Keenan, C.W., Kleinfelter, D.C., Wood, J.H., 1996, Kimia untuk Universitas, ed. ke-6 jilid 1 alih bahasa Pudjaatmaka, A.H., Erlangga, Jakarta

Kumar, Y., Agarwal, S., Srivastava, A., Kumar, S., Agarwal, G., Khan, M.Z.A., 2014, Antibacterial Activity of Clove (Syzygium aromaticum) and garlic (Allium sativum) on Different Pathogenic Bacteria, Int. J. Pure App Biosci., 2(3), 305-311.

Li, W-R., Shi, Q-S., Liang, Q., Xie, X-B., Huang, X-M., Chen, Y-B., 2014, Antibacterial Activity and Kinetics of Litsea cubeba Oil on Escherichia coli, Plos One, 9(11), 1-6

Musta, R., dan Nurliana, L., 2019, Studi Kinetika Efektifitas Minyak Daun Cengkeh (Syzygium aromaticum) sebagai Antijamur Candida albicans, Indo. J. Chem. Res., 6(2), 107-111.

Nurliana, L., Kurniawati, D., Kadir, L.A., Dewi, F., Musta, R., Nurjannah, 2019, The Effectiveness of Maltodextrin as An Adhesive in Microencapsulation of Clove Leaf Oil (Syzygium aromaticum) For 
Antibacterial Applications, Submit IOP Proceeding. $2^{\text {nd }}$ ITAPS.

Nurliana, L., Musta, R., Rudi, L., 2016, Microencapsulation of Essential Oil from Rogo Plant (Premna serratifolia L.) as antibactery Escherichia coli, Inter.J. Eng. Sci. \& Res. Tech, 7(8), 314-323.

Petrucci, R.H., 1992, Kimia Dasar Prinsip dan Terapan Modern. Alih bahasa: Suminar A. Edisi Ke-Empat, Jilid 2, Erlangga, Jakarta

Prijatmoko, D., Syafira, N.L., Lestari P.E., 2018, Antibacterial Activity of Essential Oil Extracts from Curcuma xanthorrhiza roxb. Rhizomes Against Bacteria Causing Pulp Necrosis, J. Dentomaxilloficial Sci. 3(3), 144-148.

Risnawati, Nurliana L., Kurniawati D., 2017, Mikroenkapsulasi Minyak Atsiri dari Tanaman Nilam (Pogostemon cablin Benth) sebagai antijamur Candida albicans, Indo. J. Chem. Res. 4(2), 386-393.

Saeed M, Nadeem M, Khan M.R, Shabbir M.A, Shehzad A, Amir R.M., 2013, Antimicrobial Actifity of Syzygium aromaticum Extracts Against Food Spoilage Bacterial. African J. Microbiology Research, 7(41), 4848-4856.
Soliman EA, El-Moghazy AY, El-din MSM and Massoud MA., 2013, Microencapsulation of Essential Oils Within Alginate: Formulation and In Vitro Evaluation of Antifungal Activity, J. Encapsulation and Adsorption Sciences, 3(1), 48-55.

Sudijono, A., 2015, Pengantar Statistik Pendidikan, Rajagrafindo Persada. Jakarta.

Sukardjo, 2013, Kimia Fisik, Rineka Cipta. Jakarta.

Sultana S, Shahidullah A.S.M, Islam M.dM., Wasey A.F.S.A. Nahar S., 2015, Antibacterial effect of Aqueous Neem (Azadirachta indica) leaf extract, crude neem leaf paste, and Ceftriaxone against Staphylococcus aureus, Escherichia coli and Pseudomonas aeruginosa, Malays. J. Med.Bio.Res, 2(2), 89-100.

Triyono, Bambang S., Iqmal T., 1998, Buku Ajar Kinetika Kimia. Jurusan Kimia FMIPA UGM. Yogyakarta

Uddhav, Sivagurunathan, 2016, Antibiotic Susceptibility Testing: A Review on Current Practices, Int. J. Pharm. 6(3), 1117.

Xu J-G, Liu T, Hu Q-P., Cao X-M, 2016 , Chemical Composition, Antibacterial Properties and Mechanism of Action of Essential Oil Clove Bud against Staphylococcus aureus, Molecules 21:1194 